\title{
Study on the Bottleneck and Countermeasures of the Cooperation between Universities and Enterprises in Local Universities of Jilin Province
}

\author{
LIU Shu ${ }^{1, a}$, QIAN Yuzhuo ${ }^{2, b}$ \\ ${ }^{1}$ College of Mechanical Engineering , Baicheng Normal University, Baicheng,137000,China \\ ${ }^{2}$ College of Economics and Management ,Baicheng Normal University, Baicheng,137000,China \\ aemail:2493301@qq.com, bemail:8438136@qq.com
}

Keywords: Local Universities, the Cooperation between Universities and Enterprises, Bottleneck

\begin{abstract}
At present, the reform of education system is being carried out in our country, especially for the reform of colleges and universities. Since our country is carrying out the manufacturing upgrade in 2025 , it is necessary to train more modern talents, and the most important base of training talents is colleges and universities, so that the practice ability of university students becomes very important .In order to improve the development speed and level of modern manufacturing industry in our country, it is necessary to combine the scientific research and research with each other in the training of personnel training .It can be said that improving the level and quality of production, education and research in colleges and universities will be conducive to the rapid development of the whole industry in China. The key consideration is the local universities cooperation problem. Because of their training needs and their own local combined with each other, which will require effective combination of theory and practice of research clearly visible. Local universities cooperation is the implementation of the basic research unit of China's education system reform and modernization. Therefore, the main research object of this paper is the school enterprise cooperation of local undergraduate colleges, and the various problems and phenomena should be studied. It is mainly to study the handling methods of bottlenecks, so as to improve the quality of personnel training in China.
\end{abstract}

\section{Introduction}

The cultivation of talents in local colleges and universities in China will directly promote the rapid development of the whole local industry, and the mode of cooperation between schools and enterprises is also an important way to adapt to the current reform of the education system in our country. Improving the level of cooperation between schools and enterprises is an extremely important government task in the future .Of course, in the process of this study, we need to pay attention to the bottleneck of cooperation between schools and enterprises in China, that is, the cooperation between schools and enterprises will meet an important bottleneck period in the development of colleges and universities. In this period, it is necessary to solve the problem as effectively as possible, otherwise it will affect its later development, and even bring a devastating blow to the early development. Therefore, this paper based on the current cooperation of local colleges and universities, combined with the current research situation, found the root of the bottleneck, hoping to solve this bottleneck problem for effective countermeasures. In order to continuously improve our current level of modernization and speed.

For the current new term of school-enterprise cooperation, it has the most essential content. The current cooperation between schools and enterprises in China is mainly an extension of industry-university-research. That is to say, the current cooperation between schools and enterprises is the concrete manifestation of industry, education and research. The school-enterprise cooperation can improve the quality of the education training well and improve the practical ability of the students so as to meet the requirement of the current society for the practical ability of college students .Because of the obvious problem of college students' employment at present, the main reason is that the practical ability of college students needs to be further improved, which makes the 
cooperation between schools and enterprises continue. Improving students' practical ability has become a special focus of local colleges and universities, it can be said that improving the level of cooperation between schools and enterprises is an important impetus to the reform of education system in China [1].

\section{The Bottleneck Problems Encountered in the Cooperation between Universities and Enterprises in Local Colleges and Universities}

The Basic Orientation of the School is Questionable, and the Whole Goal Lacks Accuracy. In order to adapt to the development of society and the development of government policy, we need to continuously carry out the reform of the system and mechanism in order to adapt to the reform of the education system in our country. This makes the current special attention to the cooperation of universities and enterprises, each university is also actively carrying out the project of cooperation between the school and enterprise, it can be said that the current construction of the university and enterprise cooperation is the most intense. It is also a hot research project. However, because there are many kinds of universities in China, there are many colleges and universities at all levels, which will inevitably have different levels of cooperation in policy orientation, capital support and social environment. This requires continuous improvement of our university's cooperation goals in the school enterprise cooperation. Otherwise, it will make school enterprise cooperation just a form without its essential content[2].For example, a research university needs effective combination of research institutes and research institutes when carrying out school enterprise cooperation, so that we can give full play to its effective combination of theory and practice. For the local universities studied in this paper, the units that need to cooperate with enterprises should be in the actual operation, that is, in combination with the local market needs of the premise. In order to achieve the goal of the cooperation between the university and the enterprise, the local colleges and universities are often unable to be the direction and goal of their own development. Most of the forms of cooperation between schools and enterprises are based on other universities, different levels of cooperation, which makes it difficult to carry out practical combination of enterprises and universities in the whole research process. Then wasted a lot of money and material resources, on the contrary, and not due to the effect.

Colleges and Universities Lack of Outstanding Practical Ideas. Once the school-enterprise cooperation model is determined, after solving the direction of its own development, it is necessary to train the practical ability, which will be the key factor to achieve the level and quality of school-enterprise cooperation. Teachers need to pay more attention to the outstanding practical ability in teaching and improve students' practical ability and level. In short, what is needed is that in the theoretical course, it is necessary to cultivate students ' active transmission practice , and more needs to cultivate students ' practical thinking. In another aspect, it is necessary to cultivate students ' practical ability, to carry out the study of practical courses, to further carry out the students ' practical ability and level .However, at present, for local undergraduate colleges, on the one hand, because of the problem of funds, on the other hand, because of the teacher ' $s$ own problems, the current undergraduate colleges often do not pay attention to the cultivation of the practical consciousness, simply by the lack of funds and the environmental restriction , and refuse to train the practical ability of the students , and can not carry out the training of effective practical courses. This is the key factor which can not be correctly cultivated for the practical ability in the local colleges and universities in our country at present, and the outstanding practice idea of the whole students is not obvious, which directly leads to the lack of the necessary practical consciousness of the students[3].

The local Undergraduate Colleges and Universities are Lacking in the Internship and the Outside School Practice Base. At present, the local colleges in our country enterprise cooperation in a more obvious feature is not very good, the construction of training facilities, that is to say in the project cooperation, within the school is not good practice equipment, which makes the students in social practice is not basic practice ability, also in the search for practice bases is basically a mere formality, that is to say the practice base not what practice tools and sites, which makes the practice 
construction of the practice base can't keep up with the requirements, and also reach to the aim of practice. Of course, though local colleges have some training base, but the base is basically rely on the teacher's relationship is obtained, which makes the overall planning was not long, basically in a A nominal state. It can be said that the local colleges in the process of school enterprise cooperation throughout the planning is good, but in the concrete floor plan obviously is not much maneuverability. Therefore, the phenomenon that local colleges only have a good plan, no practical place, this is the students after 4 years of undergraduate education, get some theoretical knowledge or some old idea, which is obviously not conducive to the students in to obtain sufficient competitive society. Therefore, the local colleges and universities lack of practice can be said to be a great short board of local universities in the short board if can not be filled, will seriously affect the cooperation effect.

The Teacher's Practice Level is Limited and there are Problems in the Overall Evaluation Mechanism. For local colleges and universities, the majority of teachers are basically in the school graduate doctoral students, these doctoral students obviously do not teach good practical ability, or lack of good social practical ability. This makes the teachers lack of practical ability, basically can not help students to cultivate their practical ability. However, there are also teachers with strong practical ability among teachers. These teachers often have professional qualifications, but also in the whole social practice to obtain greater experience, but often because of the educational level of these teachers, they are often unable to meet the requirements of some courses of teaching. This restricts the scope of its teaching, and thus seriously hinders its practical level of play. At the same time, the current teaching evaluation indicators are still problematic. That is to say, the current evaluation index basically adopts the original principle, which is to evaluate according to the evaluation standard of the school. But in the school evaluation, the school often occupies an important part. The evaluation of school teachers is often the evaluation of curriculum, basically does not involve the assessment of practical ability, or the assessment of practical ability is basically a product of incidental inspection. In this way because of the lack of an effective evaluation system in, this directly leads to the local colleges and universities in our country when the cooperation between schools and enterprises when there is no good enthusiasm, that is, the teachers themselves lack of enthusiasm to implement. This will directly hinder the local colleges and universities in China to implement the goal of cooperation between schools and enterprises, and thus not conducive to the development of the school itself[4].

\section{The Basic Strategy to Deal with the Bottleneck of School-Enterprise Cooperation in Local Universities and Colleges}

Focus on the Talent Demand Point of the Enterprise. For undergraduate colleges, especially for local universities, it is necessary to improve the demand of local enterprises, that is , it is necessary to combine their own professional setup with the target of local enterprise development so that they can drive the students ' employment well . Therefore, the basic principle is to promote the students ' satisfaction. This is the most important point in the competition among local universities in our country . Therefore, it is an important juncture for local undergraduate colleges to attract enterprises. Therefore, the effective cooperation mode of school - enterprise is the direction of the development of local undergraduate colleges .

Building a Good Platform for School Enterprise Cooperation. For the school-enterprise cooperation platform, it is an important platform for the industry-university-research integration of local colleges and universities in China. The construction of this platform can be very good to meet the local colleges and universities to improve the practical ability of students. For the establishment of the platform, the most important is to enhance the enthusiasm of enterprises. This is an important link in the construction of school-enterprise platform, therefore, the government needs to give various policy support after the enterprises accept a certain number of students. Only in this way can we realize the effective construction and development of our country's school-enterprise platform. At the same time, for schools, it is necessary to know what kind of talents enterprises need. Only in this way can we train professional talents for the needs of enterprises, so as to solve the 
problem of talent needs of enterprises. Through the effective activities between these two people, we can build a good platform for cooperation between schools and enterprises in our country. And then improve the cooperation level and quality of local undergraduate colleges and universities in our country[5].

Increasing the Amount of Investment and Constructing Park-style Teaching. In recent years, the employment of college students in China is more prominent, for this problem, mainly due to the continuous expansion of colleges and universities, as well as the strength of the construction of the university and enterprise platform teaching. These problems directly affect the employment quality of the current employment students in China, leading to a relatively serious employment problem. In order to effectively alleviate this problem. On the one hand, schools need to face the needs of the market to formulate effective teaching tasks and teaching objectives, so as to adapt to the needs of society, enhance the competitiveness of students employment. The government needs a great deal of money to support the overall construction of an effective campus teaching, so that it can be in a real teaching environment. Get effective talent training. Enterprises in this park can be normal production and operation, the government gives certain subsidies, students can practice in the real environment, therefore, in such a training and teaching. Students can really exercise the ability that enterprises need, not just a kind of theoretical knowledge, which is the focus of our local colleges and universities in the school-enterprise cooperation at present. This will improve the competitiveness of our local colleges and universities, and achieve a real detour beyond.

Optimize the Teaching Team and Carry out a Comprehensive Teaching Evaluation System. For professionals with strong practical ability , it is necessary to give all kinds of welfare policies so as to realize the effective promotion of teaching staff in the true sense . In addition , it is necessary to establish a more accurate teacher evaluation system . It is necessary to introduce the evaluation system of the third party so that the current teaching quality is more consistent with the requirements of the enterprise , and the evaluation of the enterprise needs to be included, which is an important part of the present important part . It is an important part to realize the reform of the teaching system in our country .

\section{Conclusion}

Local undergraduate colleges in China will inevitably encounter various problems in cooperation. When encounter a bottleneck, we need to face our own problems, to solve the problem seriously, so as to realize the true meaning of the corner beyond, to achieve its graduates effectively, and enhance the employment rate, meet the talent demand of the enterprise.

\section{Acknowledgement}

In this paper, the research was sponsored by the Educational Science Project of Jilin province during “13th Five-Year Plan” in 2017 (No. GH170587) .

\section{References}

[1]ZHOU Hongxing. Research on Bottlenecks and Countermeasures of School-Enterprise Cooperation in Local Applied Undergraduate Colleges[J].Education Exploration,2012:91-93

[2]JI Jieying. The bottleneck and Countermeasures of the implementation of the Modern Apprenticeship of Higher Occupation Education[J].Higher Education Exploration,2016:41-43

[3]WANG Xiaoqiong. Bottleneck Analysis and Countermeasures of higher Vocational Education Cooperation in production and Learning in China[J].The Ninth China University Management and Academic International Discussion,2015:121-123

[4]CHEN Changfeng .Research on the Current Situation and Countermeasures of the Training Mode of School Enterprise Cooperation in Local Universities-As an Example of a University in a 
Certain Area [J].China University Students Career Guide,2015:60-64

[5]ZHANG Lihuan. Research on the Training Mode of Financial Management Specialty in Local Applied Undergraduate Colleges based on School-Enterprise Cooperation-Take Jilin Institute of Agricultural Science and Technology as an Example [J].Tax Paying,2017:61-63 